society. The book demonstrates the (different) values of many women's studies students when it comes to employment practices, including a desire to 'work differently' and a high commitment to social change:

Their awareness and knowledge about multiple discrimination mechanisms that operate in the labour market enable them to encourage the widespread adoption of more egalitarian principles in their workplace.

An additional particularly interesting aspect of the book is that of comparative research, and the authors identify some key questions and issues for researchers working with cross-cultural differences, especially with regard to cross-cultural/ national perspectives on gender, race, ethnicity and nationality. The chapters on research processes (Chapters 7 and 8 , by Gabriele Griffin and Jalna Hanmer, respectively) explore the impact of multidisciplinarity; communication and translation; as well as comparability of databases, especially with regard to questions about race and ethnicity.

The book will then be of interest to researchers working on cross-cultural projects as well as to those working on the impact of gender differences on employment and training in Europe. Although I was at times disappointed with the lack of a thematic approach to this book, I am sure this is a text to which I shall refer in my own research as a source of information and as a valuable resource.

doi: $10.1057 /$ palgrave.fr. 9400294

Sue Jackson

\title{
Against empire: feminism, racism and the West
}

Zillah Eisenstein; Spinifex Press, Melbourne, Zed Books, London and New York, 2004, 256p, ISBN $1842777394 £ 55.00$ (Hbk); ISBN 1842777395 X £17.95 (Pbk)

Zillah Eisenstein's Against Empire is a sincere attempt from the West to think and see humanity beyond the boundaries of colour, language and power. Eisenstein tries to see 'everything/everywhere' through the politics of humanity by thinking subversively and seeing comparatively in this semi-autobiographical journey. To achieve this, she chooses a radically plural standpoint to see beyond the West; to respect humanity, freedom and democracies that have existed everywhere. For a feminist living 'elsewhere' - in the third world - it is a pleasurable and rare experience to read this Westerner, thinking in non-Western ways.

Eisenstein opposes America's empire building based on capitalist exploitation, racial discrimination and masculine militarization. Tracing the empire's past through slavery and racism, Eisenstein explains how the empire 'universalizes' and 
legitimizes exploitation and oppression through the language of terror and war. Her effort is to unmask the 'fictions' of the West by studying the Others of the West; the Muslim, the Black, the East and its colonial experiences. She seeks a notion of 'other than Western' universalism and an understanding of the contributions of non-Western, alternative democracies.

As Eisenstein rightly points out, historically, more than knowing themselves, the colonized are forced to know the colonizers (pp. 28-29). While being 'forced' by our universities to read/study many Western thinkers who brought enlightenment to the world, I have always wondered what was 'universal' about the ethics or reason endorsed by someone like Immanuel Kant, who justified racism and considered women as brainless. However, in the third world academia, even today, there is not much space for such critical and political knowing/learning.

Feminisms in the third world have struggled for decades to look beyond the dichotomies constructed by Western epistemologies, although not always successfully. Feminists from the third world have always wanted the privileged colonizer to know and see themselves more deeply and Others more humanly so that the universal could become more 'polyversal'. Eisenstein shares this search for a polyversal humanity, which is diverse, inclusive and locational, expressing a 'connectedness rooted in multiplicity' (p. 219). For her, feminisms all over the world are/shall be located in such a connectedness and unity.

In this respect, the politics of colour becomes significant for Eisenstein to explore, as she does in chapters two and three. As she points out, 'the silence about whiteness presents it as though it were not a color; and colors everything else by doing so' (p. 59). The origin of the term 'women/men of colour' has a historical significance of striving for a language of unity for the 'coloured'. But as a concept, 'women of colour' renders a meaning which shows the White as 'the colour' and others as Other colours or the White as non-coloured and the Other colours as coloured. Here language (as in the term 'women of colour') cannot escape from inventing or contributing to power hierarchies.

Human rights for Eisenstein are universal, 'humanly given to anyone who is human'. From this position she explains how the United States' talk on human rights is a type of rhetoric and how ideologies of liberal democracy and its propagators manipulate and control the human rights discourse. If Eisenstein is right in historicizing and contextualizing the human rights discourse, then the socalled alternative democracies in the third world also must have always known the meaning of this discourse and must have actively participated in it. However, the contemporary reality tends to depict 'human rights' as another new phenomenon, imported from the West. Hence it hasn't been easy for third world intellectuals/activists to contextualize it in the field or to make this term 'political' enough. This has been true historically about almost any concept imported from the West, whether 'development' or 'modernity'. 
1 Jotirao Phule

(1827-1890), E.V.

Ramaswamy Nayker (popularly known as Periyar (1879-1973), Bhimrao Ambedkar (1891-1956).
Attempts to trace the origins of exploitation and oppression are extremely relevant. However, it is also important for both the colonized and the colonizers to locate the multiplicities of oppression from within and beyond and from the nation to the Empire. And so, when we in India try to trace alternative democracies in our past, we not only read Gandhi (pp. 101-104), Tagore (pp. 106-108) or Sri Aurobindo (pp. 108-110), but also try to understand thinkers like Phule, Periyar or Ambedkar ${ }^{1}$ for their contributions towards making India meaningfully democratic.

In India, religious politics have done more harm than good to its unity. And that is why whenever Indian nationalism's imagined community stood for 'unity in diversity', India's poor, women, tribals and dalits fought for diversity - whether in Tamil Nadu, North East or Kashmir. For the white people in the West and for the upper caste in the East, a major contribution by the anti-racist/anti-casteist feminist politics will be, as Eisenstein illustrates, a humanitarianism that is polyversal. Quoting Toni Morrison, Eisenstein points out, 'Definitions belong to the definers, not the defined' ( $p .188$ ). The attempts by the West to define the Black or the Muslim belonged to the Westerners; it doesn't belong to the defined. And equally problematic has been the attempts of the East (living in the West or the non-West) to define the dalit or the subaltern.

If the polyversal world, as Eisenstein explains, wishes to have a 'view from everywhere', then feminists across the world will have to see and think more on many other fundamentalisms beyond the Muslim. Or to be more precise, Western feminists will have to tell the West to open their eyes towards Christian fundamentalism. Yet, how do third-world feminists confront the Empire? Eisenstein shows a very rarely visible passion and honesty to say that it is important for feminisms today more than ever to think polyversally and to see human bodies beyond colour and language. Yet, I was left wanting more specificity about exactly what such a polyversal account would entail and for whom. What her book contributes to is the hope that polyversal feminisms of the West and the East will see beyond boundaries created between empires and nations and the definers and the defined by capital and power.

M.S. Sreerekha

doi:10.1057/palgrave.fr. 9400295

\section{Feeding anorexia: gender and power at a treatment center}

Helen Gremillion; Duke University Press, Durham and London, 2003, 280p, ISBN 0-8223-3133-0 (Hbk) £69.00; ISBN 0-8223-3120-9 (Pbk) £16.95

Feeding Anorexia is a refreshingly original and insightful account of how anorexia is (re)constituted. Through careful ethnographic investigation and astute critical 